\title{
Major salivary glands magnetic resonance imaging
}

\author{
- Jun Ho Kim Department of Stomatology, School of Dentistry, University of São Paulo, Sao Paulo, SP, Brazil \\ - Renan Lúcio Berbel da Silva Department of Stomatology, School of Dentistry, University of São Paulo, São Paulo, \\ SP, Brazil • Luiza Warmling Department of Stomatology, School of Dentistry, University of São Paulo, São Paulo, SP, \\ Brazil - Israel Chilvarquer Department of Stomatology, School of Dentistry, University of São Paulo, São Paulo, SP, \\ Brazil • Luciana Munhoz Department of Stomatology, School of Dentistry, University of São Paulo, São Paulo, SP, Brazil
}

ABSTRACT | Objectives: To provide basic information on the magnetic resonance imaging modalities, emphasizing the diffusion-weighted imaging technique, as well as to clarify its applicability to diagnose major salivary gland disorders. Methods: The PRISMA statement was used during data assessment and extraction. The MEDLINE (PubMed) database was searched for the period from 2010 to November 2017, for studies providing basic information on the MRI modalities as well its applicability to diagnose salivary gland disorders. Data extraction included information regarding: application of MRI modalities especially ADC and DWI to diagnose major salivary gland disorders. Results: The search yielded 58 publications in MEDLINE (PubMed). The initial screening of the publications was performed using abstracts and keywords. After application of exclusion criteria, we identified a total of 9 studies as eligible to be discussed. Studies revealed two main types of MRI modalities: ADC and DWI. Most of the studies suggest that MRI can be useful as a diagnostic tool for major salivary glands. Conclusion: MRI modalities are advantageous tools for salivary gland tissue evaluations. To demonstrate the accuracy of the distinct approach methods and modalities, more studies involving a larger number of patients studied are necessary.

DESCRIPTORS | Salivary Glands; Magnetic Resonance Imaging; Diagnostic Imaging; Salivary Gland Disorders.

RESUMO | Ressonância magnética das glândulas salivares maiores • Objetivos: Fornecer informações básicas sobre as modalidades de ressonância magnética (RM), enfatizando o método da imagem ponderada em difusão, bem como apontar sua aplicabilidade para diagnosticar doenças das glândulas salivares maiores. Métodos: O método Prisma foi usado durante a extração e avaliação dos dados. As buscas foram feitas no banco de dados MEDLINE (PubMed) considerando o período de 2010 a novembro de 2017 e estudos que contivessem informações básicas sobre as modalidades de RM, bem como seu uso para diagnosticar doenças das glândulas salivares. A extração de dados incluiu informações sobre a aplicação das modalidades de RM, especialmente dos métodos de coeficiente de difusão aparente e da imagem ponderada em difusão, para diagnosticar doenças das glândulas salivares maiores. Resultados: A busca encontrou 58 publicações no MEDLINE (PubMed). A triagem inicial das publicações foi realizada usando os resumos e palavras-chave. Após a aplicação dos critérios de exclusão, um total de 9 estudos foi identificado como elegível para ser avaliado. Os estudos apontaram dois tipos principais de modalidades de RM: o coeficiente de difusão aparente e a imagem ponderada em difusão. A maioria dos estudos sugere que a RM pode ser uma útil ferramenta de diagnóstico para as glândulas salivares maiores. Conclusão: Modalidades de RM são vantajosas ferramentas para avaliações dos tecidos das glândulas salivares. São necessários mais estudos envolvendo um maior número de pacientes estudados para demonstrar a eficácia dos métodos e modalidades de abordagem distinta.

DESCRITORES | Glândulas Salivares; Imagem por Ressonância Magnética; Diagnóstico por Imagem; Distúrbios das Glândulas Salivares.

CORRESPONDING AUTHOR | • Jun Ho Kim Department of Stomatology, School of Dentistry, University of São Paulo - Avenida Professor Lineu Prestes, 2227, Butantã São Paulo, SP, Brazi • 05508-000 E-mail: jun.kim@usp.br

- Received Dec. 11, 2017 • Accepted Dec. 20, 2017

- Dol http://dx.doi.org/10.11606/issn.2357-8041.clrd.2017.141455 


\section{INTRODUCTION}

The major salivary glands (parotid, submandibular and sublingual glands) are presented in pairs and are responsible for most of saliva production. ${ }^{1}$ Saliva protects teeth and mucous membrane, as well as being of great importance for the swallowing movements. ${ }^{2}$ Saliva absence is linked to many pathologies with distinct etiologies, which requires accurate diagnosis. Multiple techniques can be used to complement the clinical examination of patients, such as imaging, serology and histopathology. ${ }^{3}$

Imaging modalities for salivary gland disorders are often selected according to the disease presentation. $^{2}$ The most common methods are sialography, ultrasound, computed tomography (CT), salivary gland scintigraphy, F-FDG positron emission tomography and magnetic resonance imaging (MRI). ${ }^{2}$ Recently, MRI is claimed to be a good method to differentiate soft tissue abnormalities in salivary glands. ${ }^{4}$

MRI provides superior results to differ distinct soft tissue types ${ }^{4}$ and is a non-invasive method without radiation hazards. ${ }^{5}$ Furthermore, MRI has a wide variety of tolls and modalities that can be applied to achieve precise diagnostic hypotheses, such as the classical T2 and T1-weighted images, diffusion-weighted imaging (DWI) and apparent diffusion coefficient (ADC), dynamic contrastenhanced (DCE) and virtual endoscopic view of the salivary gland ducts. ${ }^{6-14}$

Thus, the objective of this review is to provide basic information on the MRI modalities, emphasizing the DWI technique, as well as to clarify its applicability to diagnose salivary gland disorders.

\section{MATERIAL AND METHODS}

\section{Literature search and review}

We searched the MEDLINE (PubMed) databases for the period from 2010 to November 2017 for studies providing basic information on MRI modalities as well its applicability to diagnose salivary gland disorders. The search was restricted to English language publications, combining terms and making the appropriate changes in the keywords. The main keywords used were "ADC" OR "apparent diffusion coefficient”; "DWI” OR "Diffusion-weighted Imaging"; "MRI” OR "Magnetic resonance imaging” AND “major salivary gland”. We used both synonyms "Diffusion-weighted echoplanar MR imaging" and "Diffusion-weighted imaging" in the search.

The inclusion criteria considered original articles, systematic reviews, and book chapters for the analysis. In addition, only studies addressing the MRI modalities and its applicability as an instrument to diagnose salivary gland disorders were included. Conference abstracts were excluded from the study. The PRISMA statement was used during data assessment and extraction. ${ }^{15}$ Thus, data extraction included information regarding: the application of MRI modalities, especially ADC and DWI, to diagnose salivary gland disorders.

\section{Results of the search}

The search strategy yielded $5^{8}$ publications in MEDLINE (PubMed). The initial screening of the publications considered the abstracts and keywords, yielding 28 articles that potentially met the inclusion criteria. Book chapters were added after the manual search. We excluded 19 studies because their full texts did not met our inclusion criteria. From the analyses performed, a total of 9 studies were identified as eligible for inclusion in this review (Figure 1). 


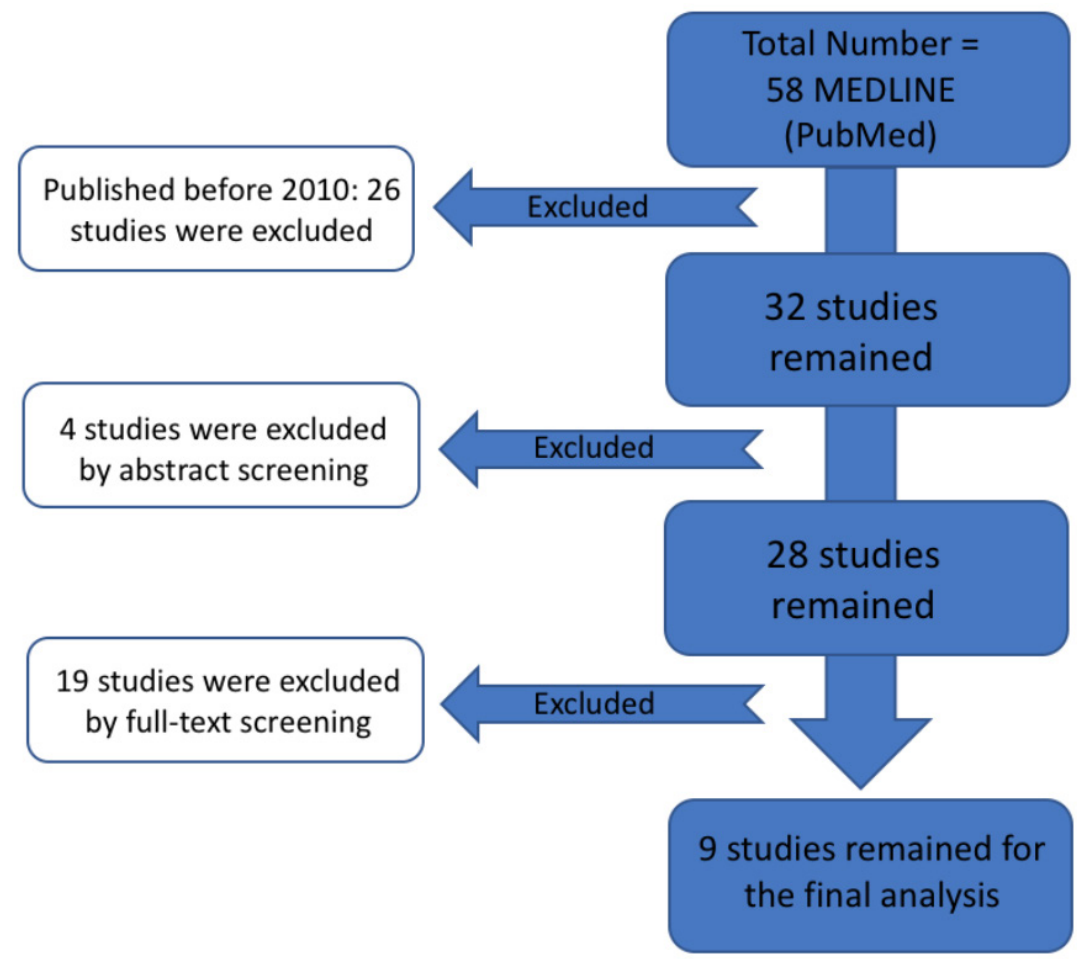

Figure 1 | Flowchart of the review: summary of our search strategy for eligible studies.

\section{DISCUSSION}

The use of MRI as a great instrument to diagnose salivary gland disorders is increasing. ${ }^{6,711,16-19}$ MRI provides multiplanar imaging with advantageous softtissue contrast using non-ionizing electromagnetic fields. ${ }^{20}$ Furthermore, MRI is useful to evaluate parenchymal masses or cystic lesions due to a better resolution of the glandular masses, internal structures, and regional extent of the lesion within adjacent tissues or spaces.

The relaxation at the end of the radio frequency pulse results in the recovery of the longitudinal magnetization; this is performed by transferring energy from an individual hydrogen nucleus (spin) to the surrounding molecules. ${ }^{21}$ Relaxation is an exponential process and the time required for $63 \%$ of the magnetization to return to equilibrium of the hydrogen atoms by this energy transfer is called $\mathrm{T} 1 .{ }^{21}$ The relaxation time in $\mathrm{T} 1$ varies on different tissues and reflects the ability of their nuclei to transfer excess energy to the surrounding tissues. ${ }^{21}$ High fluid content presents longer T1 times due to the inherent high energy of water, which inhibits the energy transfer from the hydrogen nucleus in a state of excitation. ${ }^{21}$ However, tissues with a high fat content present shorter T1 times, reflecting the lower energy levels in fat and the relative ease of transferring energy from the excited hydrogen nucleus. ${ }^{21}$

Moreover, the magnetic moments of an adjacent hydrogen nucleus start to interfere with each other at the end of the radio frequency pulse, causing the nucleus to decay and resulting in the loss of transverse magnetization. ${ }^{21}$ The time constant describing the exponential rate of transverse magnetization loss is called T2 relaxation time. ${ }^{21}$ As the transverse magnetization rapidly declines (exponentially) to zero, the amplitude and duration of the detected RF signal also declines. Relaxation in T2 occurs faster than in T1. Like T1, 
T2 relaxation times are also depend on the tissue being examined. Adipose tissues present shorter T2 relaxation time, while tissues with more fluid present longer relaxation times in T2. ${ }^{21}$ Thus, T1 and $\mathrm{T} 2$ are useful to differentiate the type of lesions and tissues.

DWI is a MRI image modality that evaluates the diffusibility of water molecules on the intercellular medium. The random movements of water molecules - named "Brownian motion"- may vary in distinct tissues and conditions. DWI is able to qualitatively detect this motion in biologic tissues, as well as any alterations. ${ }^{8}$ Resulting images are generated based on the mobility differences of the molecules. ${ }^{9}$ DWI are acquired by pairing opposing magnetic field gradients around the refocusing pulse of a T2-weighted sequence. ${ }^{9}$ Furthermore, DWI can quantify these movements by measuring the ADC values..$^{10}$ The basic major principle of $\mathrm{ADC}$ values is the quantification of free diffusivity of water molecules. On normal tissue conditions the motion of water molecules is unrestricted and no restricted diffusibility can be measured. However, in a pathological condition the diffusion of water molecules is more restricted, showing lower ADC values.

DWI and ADC can report functional changes in major salivary glands ${ }^{9}$ from any etiology and neoplasms ${ }^{11,12}$, in the ductal glandular system ${ }^{13}$ and in the acinar gland region.

DWI and ADC can be applied to complement the diagnosis of major salivary glands function after radiation-induced xerostomia, ${ }^{9}$ functional alterations inherent to Sjögren Syndrome or other immunological origin disease that compromises salivary production, Kimura Disease (KD) - a benign chronic lymphoproliferative disease with unknown etiology ${ }^{22}$. ADC presents low values in diseases that compromise the glandular function.

Extracellular substances present in salivary gland tumors also influence ADC values. ${ }^{14,23,24}$ For instance, tumors that contain abundant free water in their extracellular matrices, such as pleomorphic adenoma, fibroma or lymphosarcoma show higher ADC values.

Warthin's tumor is the most common benign salivary gland tumor, it usually presents lower ADC values, mainly due to its dense lymphoid tissue and reduced extracellular spaces. This tumor is often described and delimited as homogeneous and sometimes, as a lobulated mass that may be observed with a completely solid, mixed or cystic appearance.,11,19 Warthin's tumor is mainly composed by lymphatic and cellular components surrounded by a capsule, it has a cystic component filled with mucous membranes or fluids that resemble malignant masses. ${ }^{11}$ In this neoplasm, changing matrix and extracellular compartment structure may affect ADC values. ${ }^{11,14}$

Wang et al. ${ }^{22}$ describes $\mathrm{KD}$ as a rare, benign chronic lymphoproliferative disease with unknown etiology that typically occurs in young Asian men and frequently involves the head and neck regions, such as the salivary glands, oral cavity, and cervical lymphatic chains. Researchers ${ }^{22}$ reported KD by using magnetic resonance spectroscopic imaging method (MRSI), DWI and MRI combined with CT. The results showed that the typical characteristics of KD were subcutaneous lesions, continuously infiltrative parotid lesions with or without intraparotid lymphadenopathies, and reactive cervical lymphadenopathies on CT and MRI. On DWI, the ADC values of all subcutaneous and infiltrative parotid lesions were higher compared to those of normal parotid glands, and the ADC values of reactive lymphadenopathies were lower compared to both. Additionally, increased Choline/ Creatine ratio of lymphadenopathies (a method to evaluate the degree of malignancy of the tumors) on MRSI can further suggest the diagnosis of KD. Therefore, DWI and MRSI assessments of KD combined with CT and conventional MRI can greatly suggest the diagnosis of KD. ${ }^{22}$ 
Table 1 | Data on the studies included in the systematic review.

\begin{tabular}{|c|c|c|c|c|c|c|}
\hline Reference & MRI - Protocol & Main line of research & Conclusion & DWI & $\mathrm{ADC}$ & DCE \\
\hline Celebi et al. ${ }^{11}$ & $\begin{array}{l}\text { All MRI examinations were } \\
\text { performed on a 1.5-T MRI } \\
\text { system with an eight- } \\
\text { channel neurovascular coil }\end{array}$ & Parotid tumors & $\begin{array}{l}\text { DWI may be useful for distinguishing between } \\
\text { pleomorphic adenomas and other parotid } \\
\text { masses, particularly malignant tumors }\end{array}$ & Yes & Yes & No \\
\hline Eida et al. ${ }^{16}$ & $\begin{array}{l}\text { All MRI examinations were } \\
\text { performed on a 1.5-T MRI } \\
\text { system }\end{array}$ & Salivary gland tumors & $\begin{array}{l}\text { The autors propose a stepwise approach by } \\
\text { using multiparametric MRI (DCE and DW MRI) } \\
\text { techniques as an effective tool for differentiating } \\
\text { between benign and malignant salivary gland } \\
\text { tumors. }\end{array}$ & Yes & Yes & Yes \\
\hline Juan et al. ${ }^{26}$ & $\begin{array}{l}\text { All MRI examinations were } \\
\text { performed on a 1.5-T MRI } \\
\text { system with an eight- } \\
\text { channel neurovascular coil }\end{array}$ & Xerostomia & $\begin{array}{l}\text { The results suggest that the reduction of } \\
\text { parotid volume and increase of parotid ADC are } \\
\text { dominated by the effect of acinar loss rather } \\
\text { than edema at early to intermediate phases and } \\
\text { the following recovery of parotid volume and } \\
\text { ADC toward the baseline values might reflect the } \\
\text { acinar regeneration of parotid glands }\end{array}$ & Yes & Yes & No \\
\hline Kato et al. ${ }^{17}$ & $\begin{array}{l}\text { All MRI examinations were } \\
\text { performed on a 1.5-T MRI } \\
\text { system }\end{array}$ & Xerostomia & $\begin{array}{l}\text { DWI with a transient gustatory stimulation } \\
\text { method has potential for the evaluation of } \\
\text { patients with xerostomia }\end{array}$ & Yes & Yes & No \\
\hline Liu et al. ${ }^{18}$ & $\begin{array}{l}\text { All MRI examinations were } \\
\text { performed on a 1.5-T MRI } \\
\text { system with an eight- } \\
\text { channel neurovascular coil }\end{array}$ & Parotid glands & $\begin{array}{l}\text { Transient signal loss on DWI was successfully } \\
\text { detected by dynamic single shot echoplanar } \\
\text { diffusion-weighted image. The signal loss } \\
\text { on DWI and overestimation of ADC could be } \\
\text { partially remedied by increasing the number of } \\
\text { excitations }\end{array}$ & Yes & Yes & No \\
\hline Milad et al. ${ }^{7}$ & $\begin{array}{l}\text { All MRI examinations were } \\
\text { performed on a 1.5-T MRI } \\
\text { system }\end{array}$ & Salivary gland tumors & $\begin{array}{l}\text { The specific ability of DW-MRI to probe tissue } \\
\text { microstructures is an interesting complement } \\
\text { to the currently used imaging procedures } \\
\text { in the characterization, and even grading } \\
\text { of malignancies. ADC mapping is an easy, } \\
\text { cost effective promising tool that has neither } \\
\text { radiation exposure, nor amalgam artifacts } \\
\text { and can be used in helping characterization of } \\
\text { salivary glands lesions }\end{array}$ & Yes & Yes & No \\
\hline Takumi et al. ${ }^{19}$ & $\begin{array}{l}\text { All MRI examinations were } \\
\text { performed on a 3.0-T MRI } \\
\text { system }\end{array}$ & Salivary gland tumors & $\begin{array}{l}\text { Ultrasound fine needle aspiration cytology } \\
\text { (FNAC) is the most popular preoperative } \\
\text { examination for characterization of parotid } \\
\text { gland tumors with high accuracy in detecting } \\
\text { malignancy. However, FNAC shows sampling } \\
\text { errors and is not completely accurate with some } \\
\text { risk of malignancy being diagnosed as benign } \\
\text { lesions due to diversification of salivary gland } \\
\text { tumors, samll sample size, and location of } \\
\text { the tumor in the deep parotid lobe. Therefore, } \\
\text { preoperative MRI with DTI may be possible to } \\
\text { reduce these errors }\end{array}$ & Yes & Yes & No \\
\hline Terra et al. ${ }^{6}$ & $\begin{array}{l}\text { All MRI examinations were } \\
\text { performed on a 1.5-T MRI } \\
\text { system }\end{array}$ & $\begin{array}{l}\text { Sialadenitis and } \\
\text { pleomorphic } \\
\text { adenoma }\end{array}$ & $\begin{array}{l}\text { Within the limitations of this study, the } \\
\text { present results suggest that DWI allows for } \\
\text { differentiation between parotid sialadenitis and } \\
\text { pleomorphic adenoma }\end{array}$ & Yes & Yes & No \\
\hline Zhang et al. ${ }^{28}$ & $\begin{array}{l}\text { All MRI examinations were } \\
\text { performed on a 3.0-T MRI } \\
\text { system with an eight- } \\
\text { channel neurovascular coil }\end{array}$ & Xenostomia & $\begin{array}{l}\text { DWI combined with salivary stimulation may } \\
\text { be a potential tool for non-invasively assessing } \\
\text { salivary gland function and investigating } \\
\text { radiation-induced xerostomia }\end{array}$ & Yes & Yes & No \\
\hline
\end{tabular}


The use of different equipment and study protocols is evinced when comparing the studies. According to Table 1, only Takumi et al. ${ }^{19}$ used a 3.oT MRI system. Celebi et al. ${ }^{11}$ and Liu et al. ${ }^{18}$ used an eight-channel neurovascular coil. Other studies did not report the use of an eightchannel neurovascular coil. $6,7,16,17,19$ Additionally, we observed that seven studies used 1.5T MRI systems, ${ }^{6,711,16-18,26}$ probably due to 1.5 T MRI system being ordinary in normal routine.

Despite being a very useful method, DW-MRI is critically limited because, although it provides a microscopic view of the physiology of the tissues involved, it cannot differ the tissue components inside the voxel area?. Diffusion of water molecules inside the gland tissue is hindered primarily by cell membrane boundaries, and it can be considered to represent the combined water diffusion within the intracellular fluid (cytoplasm and organelles), the diffusion within the extracellular fluid (interstitial fluid, intravascular, lymphatic, etc.) and between intra- and extracellular compartments. The contribution of each one of these microstructural tissue changes will depend on the tissue and pathology. ${ }^{27}$

Some authors have developed their own approach to differentiate benign and malignant salivary gland tumors. Dynamic ContrastEnhanced (DCE) was used in a single investigation ${ }^{16}$ which aimed to differentiate benign and malignant salivary gland tumors combined with DWI. Eida et al. ${ }^{16}$ conceived a stepwise multiparametric approach using time-intensity curves (TICs) and ADCs. The TICs in each of the pixels of the tumor area were categorized semi automatically into one of the four TIC patterns (Types 1-4) based on the increase rate, peak time and wash ratio (upper and middle panels). If the area of the TIC type 1 is greater or equal to $30 \%$ of the region the tumor would be considered benign. If the TIC type 2 pattern was found with the ADC map with an area greater than $40 \%$ or TIC type 3 standard or TIC type 4 standard with ADC values $0.6 \times 10-3 \mathrm{~mm} 2 / \mathrm{s}$ the tumor would be considered malignant.

Despite the usefulness of different MRI modalities, many authors established their own approach methods, but there is no association between them. Thus, more studies with each approach method would be necessary to demonstrate their validity. Additionally, a meaningful limitation was identified in this review: the small number of patients studied in the investigations. To demonstrate the accuracy of the approach methods evinced in the investigations, a larger number of patients would be necessary.

All nine studies used in this review emphasized that DWI and ADC values together, can be helpful for precise diagnose of major salivary gland disorders. . $^{6,711,16-19,26,28}$

\section{CONCLUSION}

MRI modalities are advantageous methods for salivary gland tissue evaluations. To demonstrate the accuracy of the distinct approach methods and modalities, more studies involving a larger number of patients studied is necessary.

\section{REFERENCES}

1. Mosier AP, Peters SB, Larsen M, Cady NC. Microfluidic platform for the elastic characterization of mouse submandibular glands by atomic force microscopy. Biosensors. 2014;4(1):1827. doi: 10.3390/bios4010018.

2. Afzelius P, Nielsen M, Ewertsen C, Bloch KP. Imaging of the major salivary glands. Clin Physiol Funct Imaging. 2016 Jan;36(1):1-10. doi: 10.1111/cpf.12199.

3. Mandel L. Salivary gland disorders. Med Clin North Am. 2014 Nov;98(6):1407-49. doi: 10.1016/j.mcna.2014.08.008.

4. Assili S, Kazerooni AF, Ghazvini LA, Rad HS, Islamian JP. Dynamic contrast magnetic resonance imaging (DCE-MRI) and diffusion weighted MR imaging (DWI) for differentiation between benign and malignant salivary gland tumors. J Biomed Phys Eng. 2015 Dec;5(4):157-68.

5. Schlakman BN, Yousem DM. MR of intraparotid masses. AJNR Am J Neuroradiol. 1993 Sep-Oct;14(5):1173-80. 
6. Terra GT, Oliveira JX, Hernandez A, Lourenço SV, Arita ES, Cortes AR. Diffusion-weighted MRI for differentiation between sialadenitis and pleomorphic adenoma. Dentomaxillofac Radiol. 2017 Jan;46(1):1-6. doi: 10.1259/ dmfr.20160257.

7. Milad P, Elbegiermy M, Shokry T, Mahmoud H, Kamal I, Taha MS, et al. The added value of pretreatment DW MRI in characterization of salivary glands pathologies. Am J Otolaryngol. 2017 Jan-Feb;38(1):13-20. doi: 10.1016/j.amjoto.2016.09.002.

8. Friess SH, Kilbaugh TJ, Huh JW. Advanced neuromonitoring and imaging in pediatric traumatic brain injury. Crit Care Res Pract. 2012;2012:1-11. doi: 10.1155/2012/361310.

9. Dirix P, Keyzer F, Vandecaveye V, Stroobants S, Hermans R, Nuyts S. Diffusion-weighted magnetic resonance imaging to evaluate major salivary gland function before and after radiotherapy. Int J Radiat Oncol Biol Phys. 2008 Aug;71(5):136571. Doi: 10.1016/j.ijrobp.2007.12.011.

10. Singh P, Anil G. Yttrium-9o radioembolization of liver tumors: what do the images tell us? Cancer Imaging. 2013;13(4):645-57. doi: 10.1102/1470-7330.2013.0057.

11. Celebi I, Mahmutoglu AS, Ucgul A, Ulusay SM, Basak T, Basak M. Quantitative diffusion-weighted magnetic resonance imaging in the evaluation of parotid gland masses: a study with histopathological correlation. Clin Imaging. 2013 Mar-Apr;37(2):232-8. doi: 10.1016/j.clinimag.2012.04.025.

12. Sumi M, Van Cauteren M, Sumi T, Obara M, Ichikawa Y, Nakamura T. Salivary gland tumors: use of intravoxel incoherent motion MR imaging for assessment of diffusion and perfusion for the differentiation of benign from malignant tumors. Radiology. 2012 Jun;263(3):770-7. doi: 10.1148/radiol.12111248.

13. Aremu IB, Grandjean P, Hamoir M, Weynand B, Duprez T. Suggestive MR features of Whartin's tumor with correlation between diffusion-weighted imaging and pathology. JBR-BTR. 2012 Nov-Dec;95(6):379. doi: 10.5334/jbr-btr.738.

14. Matsushima N, Maeda M, Takamura M, Takeda K. Apparent diffusion coefficients of benign and malignant salivary gland tumors: comparison to histopathological findings. J Neuroradiol. 2007 Jul;34(3):183-9. doi: 10.1016/j.neurad.2007.04.002.

15. Moher D, Liberati A, Tetzlaff J, Altman DG, Prisma Group. Preferred reporting items for systematic reviews and meta-analyses: the PRISMA statement. J Clin Epidemiol. 2009;62(10):1006-12. doi: 10.1016/j.jclinepi.2009.06.005.
16. Eida S, Sumi M, Nakamura T. Multiparametric magnetic resonance imaging for the differentiation between benign and malignant salivary gland tumors. J Magn Reson Imaging. 2010 Mar;31(3):673-9. doi: 10.1002/jmri.22091.

17. Kato H, Kanematsu M, Toida M, Kawaguchi T, Shibata T, Kajita K, et al. Salivary gland function evaluated by diffusion-weighted MR imaging with gustatory stimulation: preliminary results. J Magn Reson Imaging. 2011;34(4):904-9. doi: 10.1002/jmri.22729.

18. Liu YJ, Lee YH, Chang HC, Huang TY, Chiu HC, Wang CW, et al. A potential risk of overestimating apparent diffusion coefficient in parotid glands. PLoS One. 2015 Apr;10(4):e0124118. doi: 10.1371/journal.pone.0124118.

19. Takumi K, Fukukura Y, Hakamada H, Ideue J, Kumagae Y, Yoshiura T. Value of diffusion tensor imaging in differentiating malignant from benign parotid gland tumors. Eur $J$ Radiol. 2017 Oct;95:249-56. doi: 10.1016/j.ejrad.2017.08.013. 20. Patterson DM, Padhani AR, Collins DJ. Technology insight: water diffusion MRI: a potential new biomarker of response to cancer therapy. Nat Clin Pract Oncol. 2008 Apr;5(4):22033. doi: $10.1038 /$ ncponc1073.

21. White SC, Pharoah MJ. Oral radiology: principles and interpretation. 6th ed. Saint Louis: Mosby Elsevier; 2009.

22. Wang J, Tang Z, Feng X, Zeng W, Tang W, Wu L, et al. Preliminary study of diffusion-weighted imaging and magnetic resonance spectroscopy imaging in Kimura disease. J Craniofac Surg. 2014;25(6):2147-51. doi: 10.1097/ SCS.0000000000001142.

23. Habermann CR, Arndt C, Graessner J, Diestel L, Petersen KU, Reitmeier F, et al. Diffusion-weighted echo-planar MR imaging of primary parotid gland tumors: is a prediction of different histologic subtypes possible? AJNR Am J Neuroradiol. 2009;30(3):591-6. doi: 10.3174/ajnr.A1412.

24. Yuan Y, Tang W, Jiang M, Tao X. Palatal lesions: discriminative value of conventional MRI and diffusion weighted imaging. Br J Radiol. 2016 Mar;89(1059):1-7. doi: 10.1259/ bjr.20150911.

25. Vaid S, Chandorkar A, Atre A, Shah D, Vaid N. Differentiating recurrent tumours from post-treatment changes in head and neck cancers: does diffusion-weighted MRI solve the eternal dilemma? Clin Radiol. 2017;72(1):74-83. doi: 10.1016/j. crad.2016.09.019.

26. Juan CJ, Cheng CC, Chiu SC, Jen YM, Liu YJ, Chiu HC, et al. Temporal evolution of parotid volume and parotid apparent diffusion coefficient in nasopharyngeal carcinoma patients 
treated by intensity-modulated radiotherapy investigated by magnetic resonance imaging: a pilot study. PLoS One. 2015 Aug;10(8):e0137073. doi: 10.1371/journal.pone.0137073.

27. Hagmann P, Jonasson L, Maeder P, Thiran JP, Wedeen VJ, Meuli R. Understanding diffusion MR imaging techniques: from scalar diffusion-weighted imaging to diffusion tensor imaging and beyond. Radiographics. 2006 Oct;26(Suppl 1):S205-23. doi: 10.1148/rg.26sio65510.

28. Zhang Y, Ou D, Gu Y, He X, Peng W, Mao J, et al. Diffusion-weighted MR imaging of salivary glands with gustatory stimulation: comparison before and after radiotherapy. Acta Radiol. 2013 Oct;54(8):928-33. doi: 10.1177/0284185113491089. 